\title{
Quality Characteristics and Washability Treatment of Nickeliferous Iron Ore of Agios Athanasios Deposit (Kastoria, Greece)
}

\author{
Konstantina Gkoutzioupa ${ }^{1}$, Georgios Alevizos ${ }^{1}$, Antonios Stratakis ${ }^{1}$, Evaggelos Petrakis ${ }^{1}$, \\ Athanasios Apostolikas ${ }^{2}$ \\ ${ }^{1}$ School of Mineral Resources Engineering, Technical University of Crete, Chania, Greece \\ ${ }^{2}$ GMMSA LARCO, Athens, Greece \\ Email:kgoutzioupa@isc.tuc.gr, alevizos@mred.tuc.gr, astratak@mred.tuc.gr,vpetraki@mred.tuc.gr, \\ athanasios.apostolikas@larco.gr
}

Received 18 February 2016; accepted 16 April 2016; published 19 April 2016

Copyright (c) 2016 by authors and Scientific Research Publishing Inc.

This work is licensed under the Creative Commons Attribution International License (CC BY).

http://creativecommons.org/licenses/by/4.0/

(c) ()

\section{Abstract}

The Agios Athanasios ore deposit is located within the wider area of Ieropigi in Kastoria, Greece. The specific ore deposit is developed in form of layers between ophiolites and Tertiary molassic conglomerates. The main mineralogical components are hematite, goethite, quartz, and secondarily, garnierite, lizardite, saponite, willemzeite and sepiolite, while scarcers are chromite, calcite and nepouite. Nickel is mainly found in garnierite, willemzeite and nepouite, which in coexistence with quartz are the main components in the binder material of the ore. For the mineral processing gravimetric and magnetic separations are used in the size of fractions $-8+4 \mathrm{~mm},-4+1 \mathrm{~mm},-1+$ $0.250 \mathrm{~mm}$ and $-0.250+0.063 \mathrm{~mm}$. The chemical and mineralogical analysis in combination with microscopic examination showed that mineral processing by gravimetric separation gave the most satisfactory results for the size fraction $-1+0.250 \mathrm{~mm}$.

\section{Keywords}

Nickeliferous Iron Ore Deposit, Mineral Processing, Ore Microscopy, Kastoria

\section{Introduction}

Nickel is a chemical element which cannot be encountered purely in nature. It is found as sulfides, oxides and inorganic salts. Nickel presents great affinity with iron, cobalt and copper. Therefore, they coexist in many types of deposits and may replace one another to a great extent. This is of great significance, as it can be easily 
blended with many metals, forming alloys and thereby increasing the strength, hardness, resistance to erosion or corrosion, elasticity, good thermal and electrical conductivity of the alloy to a large temperature range. Nickel-containing materials play a major role in our everyday lives-food preparation equipment, mobile phones, medical equipment, transport, buildings, power generation - the list is almost endless. About $90 \%$ of nickel production every year goes into alloys, two-thirds of each going into stainless steel [1] [2].

According to their genesis, nickeliferous ores belong to the following categories: 1) sulfurous deposits (pentlandites); 2) lateritic deposits (garnierites, limonites); 3) sedimentary deposits [1] [2]. Greek nickel deposits are originated from lateritization of ultrabasic rocks of Mesozoic. Lateritization is the nickel deposit creation procedure by weathering of ultramafic rocks in diverse geological periods and in different weathering profiles, which are genetically related to the underlying rocks [3] [4]. The products of weathering underwent to complex geological processes which led to the final deposits "nickeliferous iron ore". In Greece there were favorable conditions for the formation of laterites during the Lower Cretaceous, due to the occurrence of tropical or subtropical climate and extensive superficial spread of ophiolites. They are characterized as "fossilized" and are covered by limestone of the Upper Cretaceous (Cenomanian-Senonion) or sediments of Miocene. Their average content in nickel ranges from $0.8 \%$ to $1.5 \%$ approximately and therefore can be considered as a source of nickel. Nickel chlorite constitutes the main nickel bearer while other nickel minerals have been discovered of lesser significance, such as serpentine (nepouite), talc (willemseite), montmorillonite, takovite. The lateritic profiles vary greatly not only in thickness and continuity between individual zones, but also in the mineralogy and chemistry of the zones even over short distances. They are mainly identified the following lateritic zones: Bedrock, Saprolite zone, Clay zone and Goethitic (oxidic zone) [4] [5].

In Greece, there are more than 110 nickel iron-ore occurrences with nickel content ranging from 0.4 up to $1.2 \%$ and iron from $20 \%$ to $79 \%$. The total reserves are estimated to be over than $500 \mathrm{Mt}$ of which the $200 \mathrm{Mt}$ are exploitable. The mineral resources of lateritic nickeliferous iron-ore deposits are spread mostly in areas of Euboea, Boeotia and Kastoria. The Greek laterites are exploited by the nickel producing company LARCO GMMSA, which is the most important company in producing Fe-Ni alloy in Greece $(2 \%-3 \%$ of the total world production of nickel) [6] [7].

\section{Geology}

The Agios Athanasios ore deposit is located within the wider area of Ieropigi in Kastoria, Greece. The area under investigation belongs mainly to the zone of Eastern Greece (Sub-pelagonian) and partly to the Pelagonian zone. The area's geological structure is represented by formations of the Sub-pelagonian zone. Moreover, the Kastoria Fe-Ni deposit is overlain by Tertiary molassic conglomerates (Figure 1). Sub-Pelagonian and Pelagonian geotectonic zones are mainly characterized by serpentinised ultramafic rocks (ophiolites) aged from Upper Jurassic to Lower Cretaceous [8]. The two zones generally lie on the western segment of the Internal Hellenides and for decades have been investigated in depth to their structural geology, geochemistry and petrology. In lithological terms granites, ortho- and paragneisses as well as ophiolites are mainly found in the area [9]. A characteristic transition from the volcano-sedimentary rock sequence in carbonates has been also characteristically described around Kastoria [10]. The nickeliferous iron ores in the area appear to be a layer full of discontinuities, which consists of serpentinised ultramafic rocks and sediments on top of them. In a narrow zone extending in a NW-SE direction from Albania to the south Kastoria appear outcrops of ophiolitic rocks which compromised largely by ultramafic rocks. These ultramafic rocks are characterized by a network of veins, which are epigenetic in origin and consist of quartz, calcite and greenish nickel-bearing silicate minerals [11]. According to Mountrakis [12], the most usual rocks are mainly serpentinised peridotites, dunites, spilitised mafic volcanics and siliceous sediments. Regarding to the ophiolites in the area, they have shown a Late Jurassic to Early Cretaceous deformation and Tertiary to recent sediments [9].

\section{Experimental}

The mineralogical examination of the nickeliferous ore was carried out using the X-ray diffraction method (XRD). The automated X-ray diffractometer, D8 Advance of Bruker AXS Company was used. The identification of the ore minerals, the description of the fabric and the examination of the intergrowth in the different products were performed with an ore microscopy. A JENA ore microscope equipped with an OLYMPUS digital camera was used. The mineralogical characteristics of the ore samples have been investigated by using a scanning 


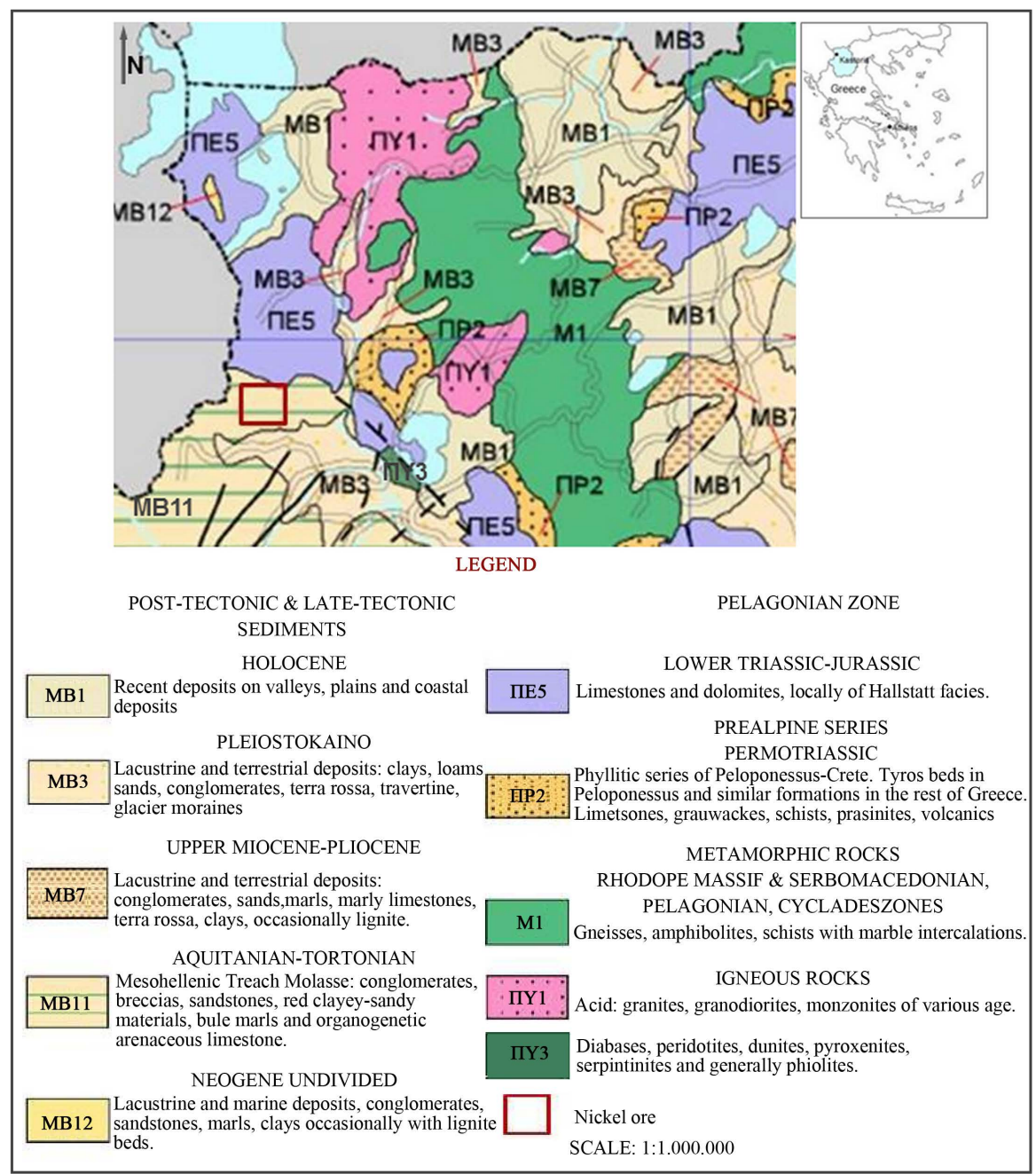

Figure 1. Modified geological map of Agios Athanasios (Kastoria, Greece).

electron microscope (SEM) type Jeol JSM 5400 in conjunction with EDS-microanalyses. The chemical analysis of nickeliferous ore was carried out using the automated X-ray fluorescence spectrometer (XRF), S2 Ranger of Bruker AXS Company. For the gravimetric separation of nickeliferous ore samples, the heavy liquid tetrabromoethane was used, which has density $2.96 \mathrm{~g} / \mathrm{cm}^{3}$. The magnetic separation was performed with the Perm Roll Magnetic Separator made by IMPROSYS and with the high intensity Induced Roll Magnetic Separator MIH 111-5 made by Carpco.

\section{Mineralogy}

The ore sampling was held by the lateritic nickeliferous ore deposit of Agios Athanasios in Kastoria area, Greece. The mineralogical study was performed to representatives' samples of the investigated ore by starting from the base towards to the top of the deposit. Above the underlying rock (ophiolites), there are successive layers of silicate ore, saprolithic ore, clay ore and iron ore zone (limonite iron ore and manganese oxides iron ore) (Figure 2). The deposit is covered by molassic conglomerates.

The microscopic examination and X-ray diffraction analysis (Figure 3) showed more or less the presence of quartz and lizardite in all samples. Especially in the bottom section of the deposit, the silicate ore, there are mainly found quartz, lizardite, garnierite (nickel antigorite) and willemseite (nickel talc), as well as occasionally sepiolite and nepouite (nickel serpentine), while hematite is in a smaller percentage. Quartz is mainly formed on compact masses. Garnierite is observed in the binder material between the quartz masses as well as lizardite. 


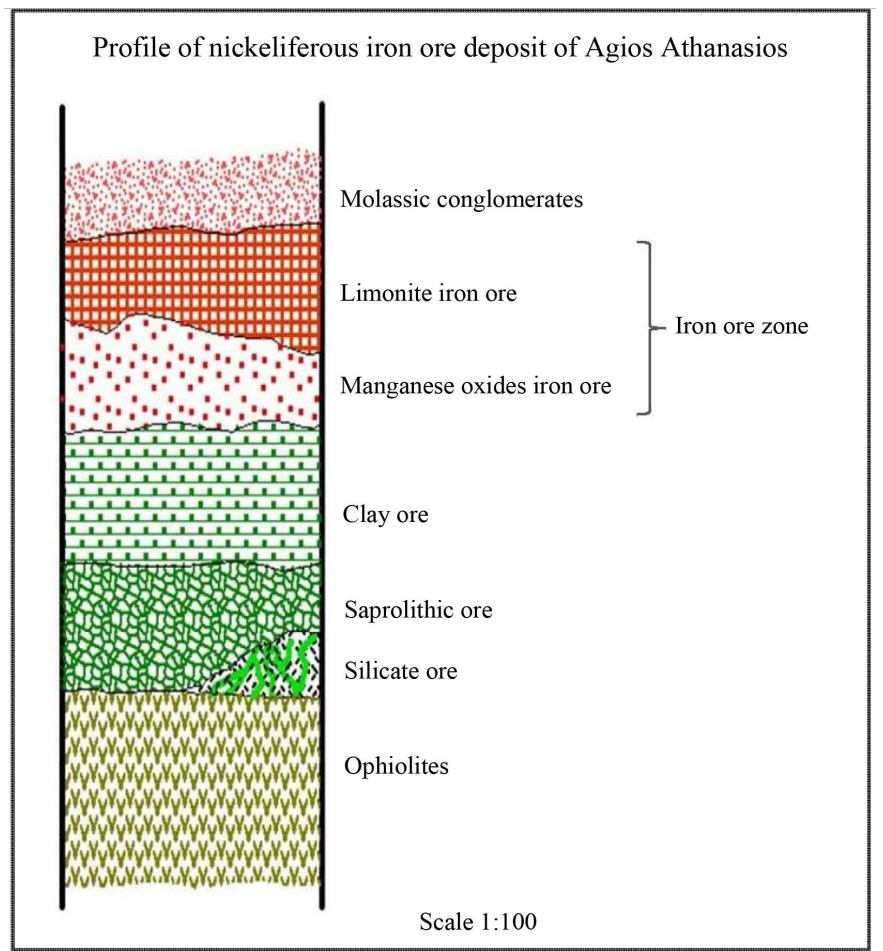

Figure 2. Geological profile of the nickeliferous deposit of Agios Athanasios (Kastoria, Greece).

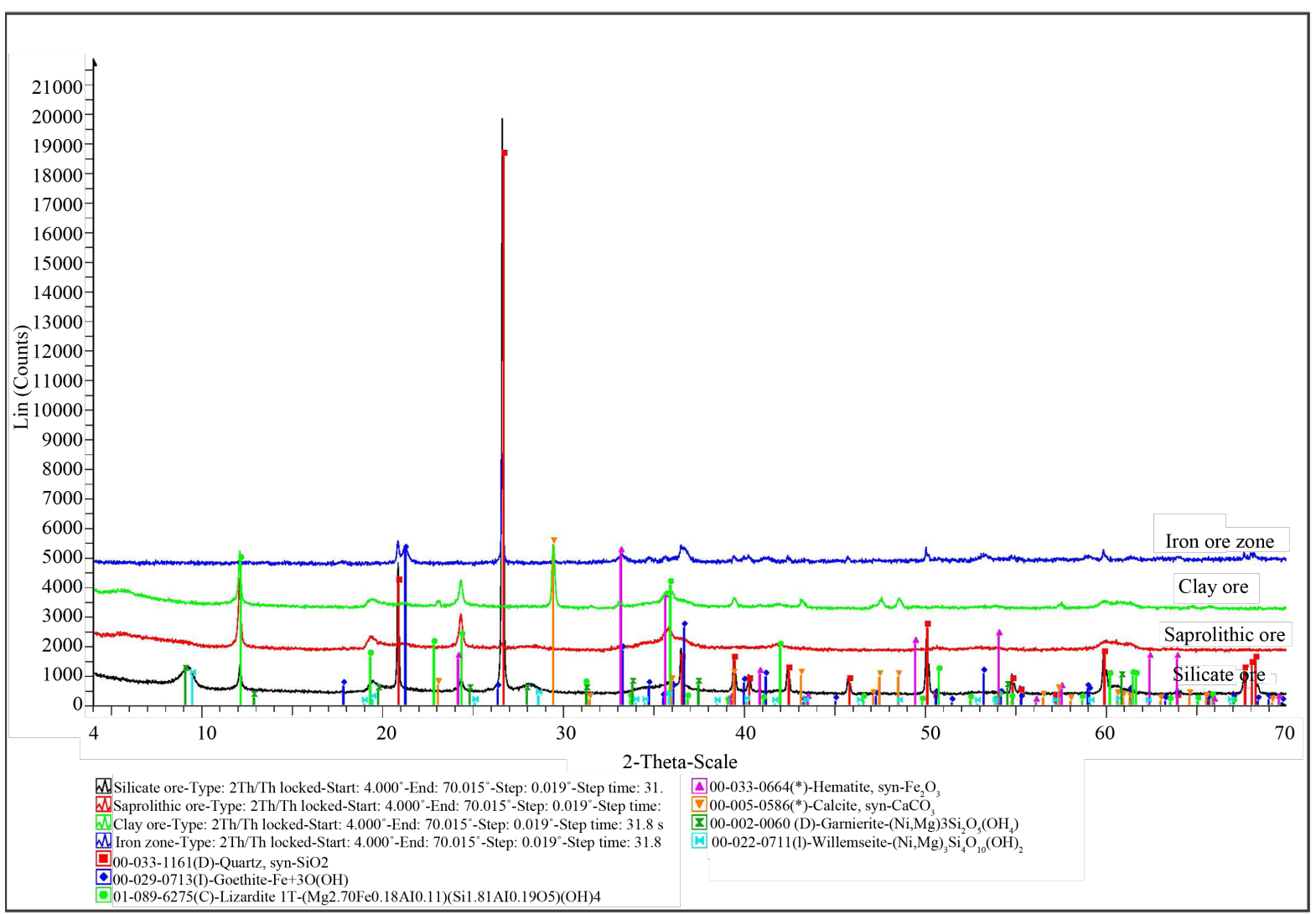

Figure 3. X-ray diffraction patterns of representative samples from various parts of the deposit profile. 
Occasionally, ferruginisation is identified in the form of hematite replacing the binder material.

The mineralogical analysis in the saprolite ore zone showed the presence mainly of lizardite, while to a smaller percentage was observed hematite, goethite, quartz, sepiolite, saponite, garnierite, willemzeite and chromite. The ferruginisation occurs in a very small degree in the form of individual grains of goethite, which alters progressively into hematite due to dehydration. The binder material (matrix) is mainly constituted of lizardite and partially by saponite and garnierite. Micro-analyses in the binder material confirmed the presence of lizardite and garnierite, submitted partially to replacement by ferrous solutions (Figure 4). Furthermore, the chromite crystals are usually multiply cracked, showing thus a characteristic cataclastic texture.

Next zone is the clay ore, which mainly consists of calcite, lizardite and to a lesser extent, saponite and willemzeite. Goethite and hematite are recorded as iron mineralization. The binder material's main mass is constituted of lizardite and, partially, of saponite and willemzeite, while calcite is encountered in form of veins within the binder material and is considered of secondary origin. Goethite is also observed in form of thin veins scattered in the matrix.

The upper iron ore zone consists of goethite, hematite and quartz, while in a smaller extent were recorded chromite, saponite and garnierite. Quartz is found in the form of compact masses, but also in the form of individual grains. The binder material between the grains is constituted mainly of saponite and garnierite. Individual chromite grains were observed scattered in the matrix, which are characterized by multiple cracks (cataclastic
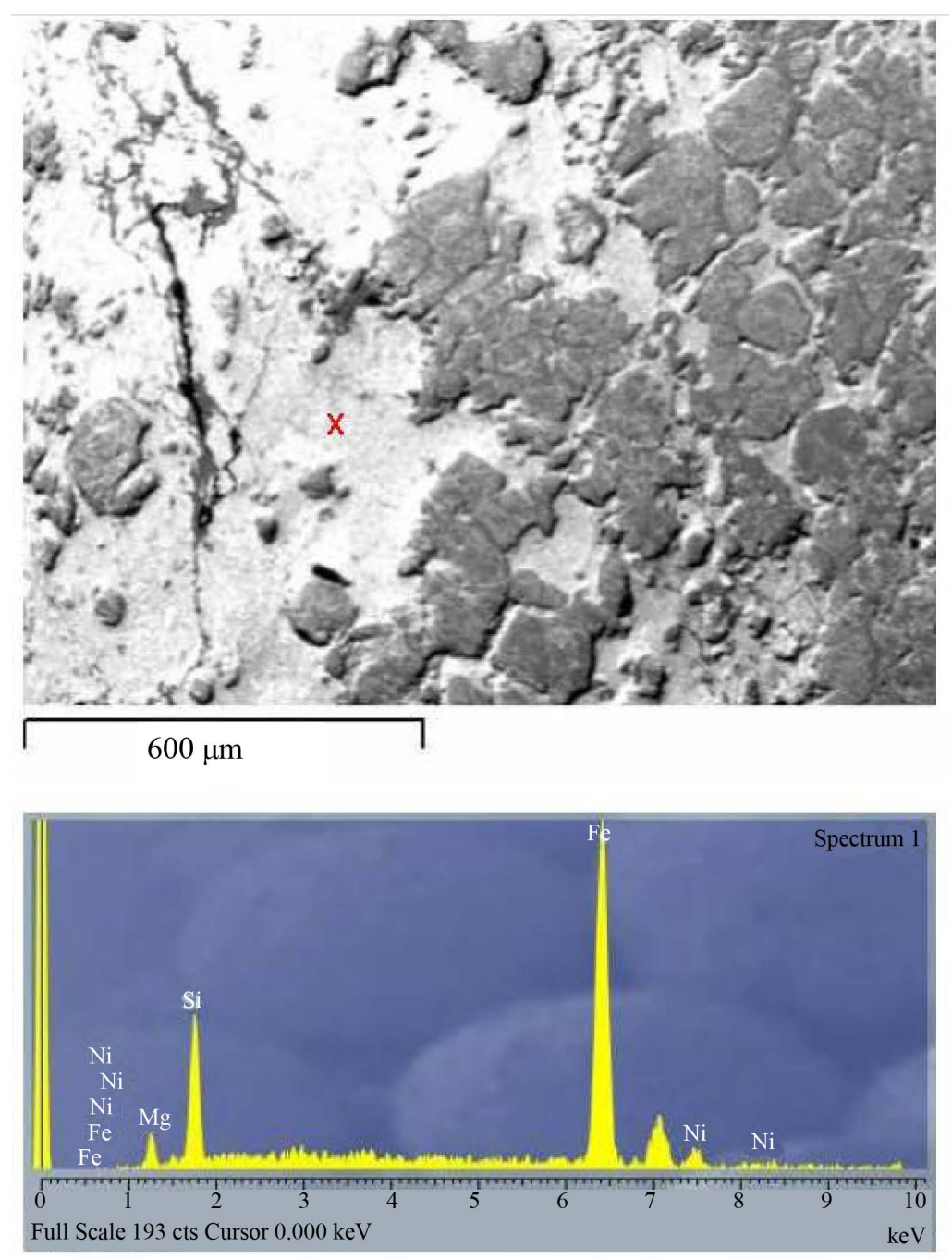

Figure 4. A SEM image and EDS-analysis of nickeliferous binder material (garnierite), submitted to replacement by iron ores $(\times 100)$. 
texture). The ferruginisation is encountered occasionally within the binder material, mainly as goethite and partially as hematite, in the form of veins, showing an epigenetic origin. Goethite has progressively transforms into hematite through dehydration (Figure 5).

The chemical analyses of representative samples collected from various parts of the nickeliferous ore deposit are presented in Table 1.

The $\mathrm{SiO}_{2}$ is mainly present in quartz so as in the silicate phases (lizardite, garnierite, willemseite, sepiolite, saponite), while $\mathrm{Fe}_{2} \mathrm{O}_{3}$ is mainly present in ferrous minerals (goethite and hematite) and secondary in chromite. Nickel is mainly present in garnierite and secondary in willemseite and nepouite. The highest content of the $\mathrm{NiO}$ is observed in the silicate ore zone $(4.06 \%)$.

\section{Washability Treatment}

A jaw crusher was used in order to crush the collected bulk sample at size $-8 \mathrm{~mm}$. The product of the jaw crusher was sieved into fractions $-8+4 \mathrm{~mm},-4+1 \mathrm{~mm},-1+0.250 \mathrm{~mm}$ and $-0.250+0.063 \mathrm{~mm}$. All size fractions were used for both magnetic and gravimetric separation tests. The fine fraction $-0.063 \mathrm{~mm}$ was not used, because it was not suitable for these mineral processing tests. Table 2 shows the results obtained from the chemical analysis of the size fractions produced. $\mathrm{SiO}_{2}$ and $\mathrm{Fe}_{2} \mathrm{O}_{3}$ are the major oxides which are found during the whole process. The highest $\mathrm{SiO}_{2}$ content is found mainly in the coarser size fraction $-8+4 \mathrm{~mm}$, while the highest $\mathrm{Fe}_{2} \mathrm{O}_{3}$ content is present mainly in the fraction $-4+1 \mathrm{~mm}$. The quality of $\mathrm{NiO}$ is higher in the $-1+$ $0.250 \mathrm{~mm}$ size fraction. However, the finer size fraction $-0.063 \mathrm{~mm}$ has also a quite high $\mathrm{NiO}$ content $(1.87 \%)$.

\subsection{Gravimetric Separation}

The gravimetric separation of the ore was carried out using tetrabromoethane which is a heavy liquid with density $2.96 \mathrm{~g} / \mathrm{ml}$. Table 3 presents the results of the gravimetric separation of the size fractions $-8+4 \mathrm{~mm},-4+1$ $\mathrm{mm},-1+0.250 \mathrm{~mm}$ and $-0.250+0.063 \mathrm{~mm}$. As apparent from these results, the weight percentages of the

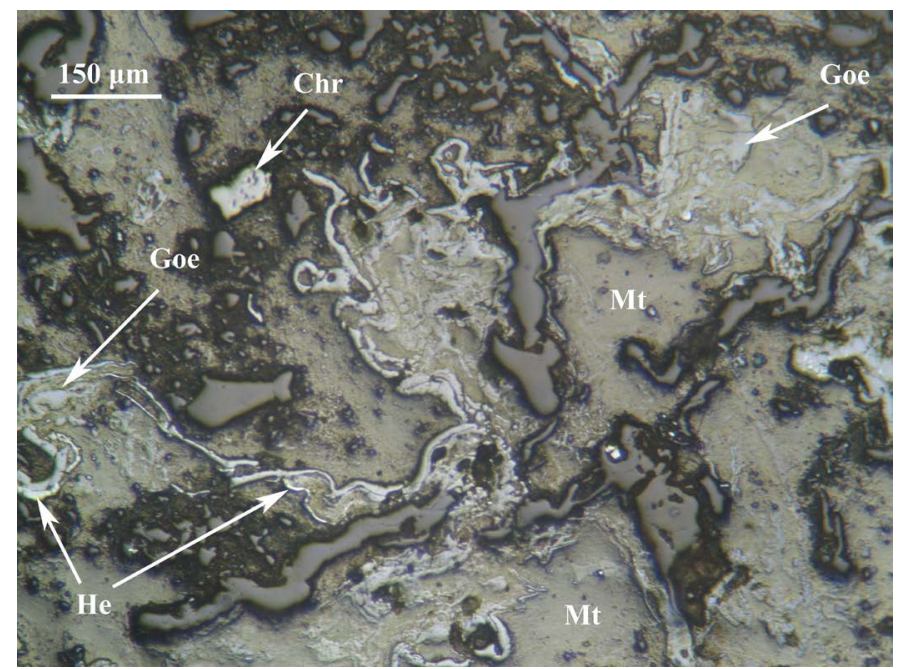

Figure 5. Goethite (Goe) transforms progressively into hematite (He) through dehydration in coexistence with chromite (Chr) clastic grains and binder material (Mt).

Table 1. Chemical composition (wt \%) of representative samples from various parts of the deposit profile.

\begin{tabular}{ccccccccccccc}
\hline Sample & $\mathrm{Fe}_{2} \mathrm{O}_{3}$ & $\mathrm{SiO}_{2}$ & $\mathrm{Cr}_{2} \mathrm{O}_{3}$ & $\mathrm{NiO}$ & $\mathrm{MnO}$ & $\mathrm{CoO}$ & $\mathrm{Al}_{2} \mathrm{O}_{3}$ & $\mathrm{CaO}$ & $\mathrm{MgO}$ & $\mathrm{K}_{2} \mathrm{O}$ & LOI & $\mathrm{SUM}$ \\
\hline Silicate ore & 3.29 & 65.51 & 0.15 & 4.06 & 0.02 & 0.05 & 0.85 & 0.84 & 18.75 & 0.05 & 6.40 & 99.98 \\
Saprolithic ore & 20.91 & 35.89 & 0.78 & 2.19 & 0.15 & 0.03 & 0.73 & 0.85 & 21.66 & 0.09 & 16.50 & 99.78 \\
Clay ore & 18.18 & 28.09 & 0.80 & 2.10 & 0.15 & 0.03 & 0.54 & 8.21 & 20.41 & 0.04 & 21.60 & 100.16 \\
Iron ore zone & 58.59 & 21.79 & 2.30 & 0.73 & 1.28 & 0.04 & 1.86 & 0.98 & 1.62 & 0.06 & 9.95 & 99.20 \\
\hline
\end{tabular}


Table 2. Chemical analysis of size fraction from initial sample.

\begin{tabular}{cccccccccccccc}
\hline $\begin{array}{c}\text { Size fraction } \\
(\mathrm{mm})\end{array}$ & $\begin{array}{c}\text { Weight } \\
(\%)\end{array}$ & $\begin{array}{c}\mathrm{Fe}_{2} \mathrm{O}_{3} \\
(\%)\end{array}$ & $\begin{array}{c}\mathrm{SiO}_{2} \\
(\%)\end{array}$ & $\begin{array}{c}\mathrm{Cr}_{2} \mathrm{O}_{3} \\
(\%)\end{array}$ & $\begin{array}{c}\mathrm{NiO} \\
(\%)\end{array}$ & $\begin{array}{c}\mathrm{MnO} \\
(\%)\end{array}$ & $\begin{array}{c}\mathrm{CoO} \\
(\%)\end{array}$ & $\begin{array}{c}\mathrm{Al}_{2} \mathrm{O}_{3} \\
(\%)\end{array}$ & $\begin{array}{c}\mathrm{CaO} \\
(\%)\end{array}$ & $\begin{array}{c}\mathrm{MgO} \\
(\%)\end{array}$ & $\begin{array}{c}\mathrm{K}_{2} \mathrm{O} \\
(\%)\end{array}$ & $\begin{array}{c}\mathrm{LOI} \\
(\%)\end{array}$ & $\begin{array}{c}\mathrm{SUM} \\
(\%)\end{array}$ \\
\hline$-8+4$ & 46.88 & 22.75 & 52.02 & 0.99 & 1.20 & 0.48 & 0.03 & 1.29 & 0.85 & 9.16 & 0.04 & 10.64 & 99.44 \\
$-4+1$ & 29.93 & 26.11 & 43.43 & 0.87 & 1.64 & 0.54 & 0.03 & 1.90 & 1.34 & 14.90 & 0.06 & 9.00 & 99.82 \\
$-1+0.250$ & 11.01 & 22.61 & 48.44 & 0.81 & 2.88 & 0.45 & 0.03 & 0.81 & 1.56 & 20.47 & 0.08 & 1.38 & 99.52 \\
$-0.250+0.063$ & 7.78 & 20.20 & 48.13 & 0.92 & 2.60 & 0.38 & 0.03 & 0.55 & 1.35 & 22.14 & 0.09 & 3.50 & 99.90 \\
-0.063 & 4.42 & 19.21 & 44.13 & 0.99 & 1.87 & 0.34 & 0.03 & 1.24 & 1.13 & 16.95 & 0.05 & 13.76 & 99.68 \\
\hline
\end{tabular}

Table 3. Results of gravimetric separation.

\begin{tabular}{|c|c|c|c|c|c|c|c|c|c|}
\hline \multirow{2}{*}{ Size fraction $(\mathrm{mm})$} & \multirow{2}{*}{ Products } & \multicolumn{2}{|c|}{ Weight (\%) } & \multicolumn{3}{|c|}{ Chemical analysis (\%) } & \multicolumn{3}{|c|}{ Distribution (\%) } \\
\hline & & of the fraction & of the initial & $\mathrm{Fe}_{2} \mathrm{O}_{3}$ & $\mathrm{SiO}_{2}$ & $\mathrm{NiO}$ & $\mathrm{Fe}_{2} \mathrm{O}_{3}$ & $\mathrm{SiO}_{2}$ & $\mathrm{NiO}$ \\
\hline & Float & 88.2 & 35.8 & 13.57 & 69.23 & 1.45 & 66.20 & 95.36 & 94.01 \\
\hline \multirow[t]{3}{*}{$-8+4$} & Sink & 11.8 & 4.8 & 51.97 & 25.25 & 0.69 & 33.80 & 4.64 & 5.99 \\
\hline & Total & 100 & 40.5 & 18.09 & 64.06 & 1.36 & 100 & 100 & 100 \\
\hline & Float & 84.2 & 24.4 & 15.82 & 50.21 & 1.34 & 60.59 & 92.00 & 91.38 \\
\hline \multirow[t]{3}{*}{$-4+1$} & Sink & 15.8 & 4.6 & 54.99 & 23.34 & 0.68 & 39.41 & 8.00 & 8.62 \\
\hline & Total & 100 & 28.9 & 21.99 & 45.97 & 1.24 & 100 & 100 & 100 \\
\hline & Float & 86.1 & 11.2 & 13.93 & 48.47 & 2.58 & 60.39 & 93.94 & 94.49 \\
\hline \multirow[t]{3}{*}{$-1+0.250$} & Sink & 13.9 & 1.8 & 56.43 & 19.32 & 0.93 & 39.61 & 6.06 & 5.51 \\
\hline & Total & 100 & 13.0 & 19.85 & 44.41 & 2.35 & 100 & 100 & 100 \\
\hline & Float & 87.1 & 5.8 & 12.79 & 44.40 & 2.19 & 68.64 & 92.20 & 92.15 \\
\hline \multirow[t]{2}{*}{$-0.250+0.063$} & Sink & 12.9 & 0.9 & 39.64 & 25.48 & 1.27 & 31.36 & 7.80 & 7.85 \\
\hline & Total & 100 & 6.7 & 16.24 & 41.96 & 2.07 & 100 & 100 & 100 \\
\hline-0.063 & Total & 100 & 10.9 & 19.21 & 44.13 & 1.87 & 100 & 100 & 100 \\
\hline Grand Total & & 100 & & & & & & & \\
\hline
\end{tabular}

floats are by far higher compared to those of the sinks for all size fractions. In general, the results obtained are satisfactory as in each fraction the float has a very high nickel content. In particular, the results of size fraction $-8+$ $4 \mathrm{~mm}$ are quite satisfactory as the $\mathrm{NiO}$ content is $1.45 \%$ in the floats and $0.69 \%$ in the sinks. The weight distribution in this fraction is $94.01 \%$ in the floats and $5.99 \%$ in the sinks, which is an indication that the greater quantity of $\mathrm{NiO}$ goes to the float products. The previous results are also obtained by microscopic examination of this size fraction. At the size fraction $-4+1 \mathrm{~mm}$ (Figure 6(a)), the results are quite similar to the previous ones. The $1.34 \%$ content of $\mathrm{NiO}$ in the floats is high but lower than the one in the floats of the $-8+4 \mathrm{~mm}$ fraction. The weight distribution in this fraction is $91.38 \%$ in the floats and $8.62 \%$ in the sinks. The results of size fraction $-1+0.250 \mathrm{~mm}$ are very satisfactory since the $\mathrm{NiO}$ content $(2.58 \%$ in the floats $)$ is the highest quality of the whole process (Figure 6(b), Figure 7). The weight distributions are $94.49 \%$ and $5.51 \%$ in the floats and in the sinks, respectively. Similar results can be revealed for the size fraction $-0.250+0.063 \mathrm{~mm}(2.19 \%$ and $1.27 \%$ in the floats and the sinks, respectively). Although the high quality of $\mathrm{NiO}$ observed in the floats, the $\mathrm{NiO}$ content in the sinks $(1.27 \%)$ is an unsatisfactory factor for the gravimetric separation at this size fraction. However, the weight distribution in the floats $(92.15 \%)$ still remains high.

\subsection{Magnetic Separation}

For the magnetic separation of fractions $-8+4 \mathrm{~mm}$ and $-4+1 \mathrm{~mm}$ the Perm Roll separator (equipped with permanent magnets) was used. According to the procedure, each size fraction was separated in two or three 




(a)

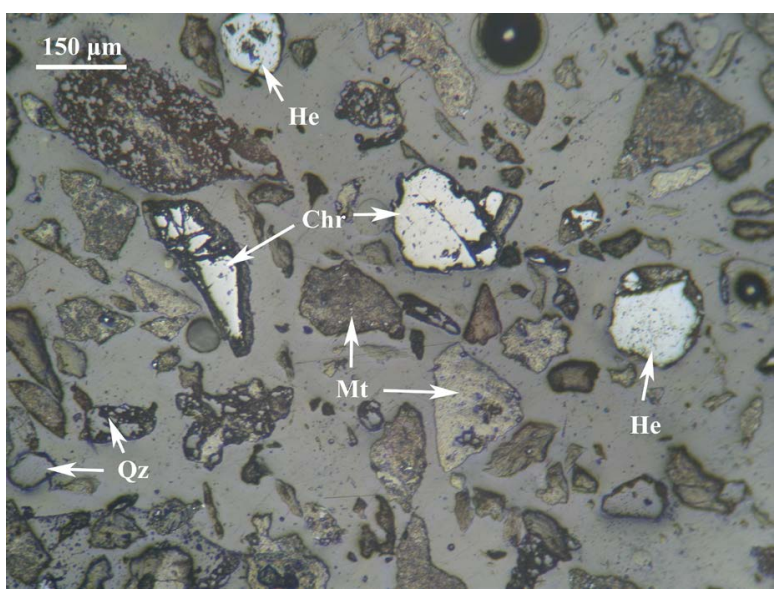

(b)

Figure 6. (a) Quartz (Qz) grains in coexistence with matrix (Mt) and traces of hematite (He) (float, size fraction $-4+1 \mathrm{~mm}$ ); (b) Chromite (Chr), quartz $(\mathrm{Qz})$ and hematite $(\mathrm{He})$ grains in coexistence with matrix (Mt) (sink, size fraction $-1+0.250$ $\mathrm{mm})$. Reflected light, //Nicols.

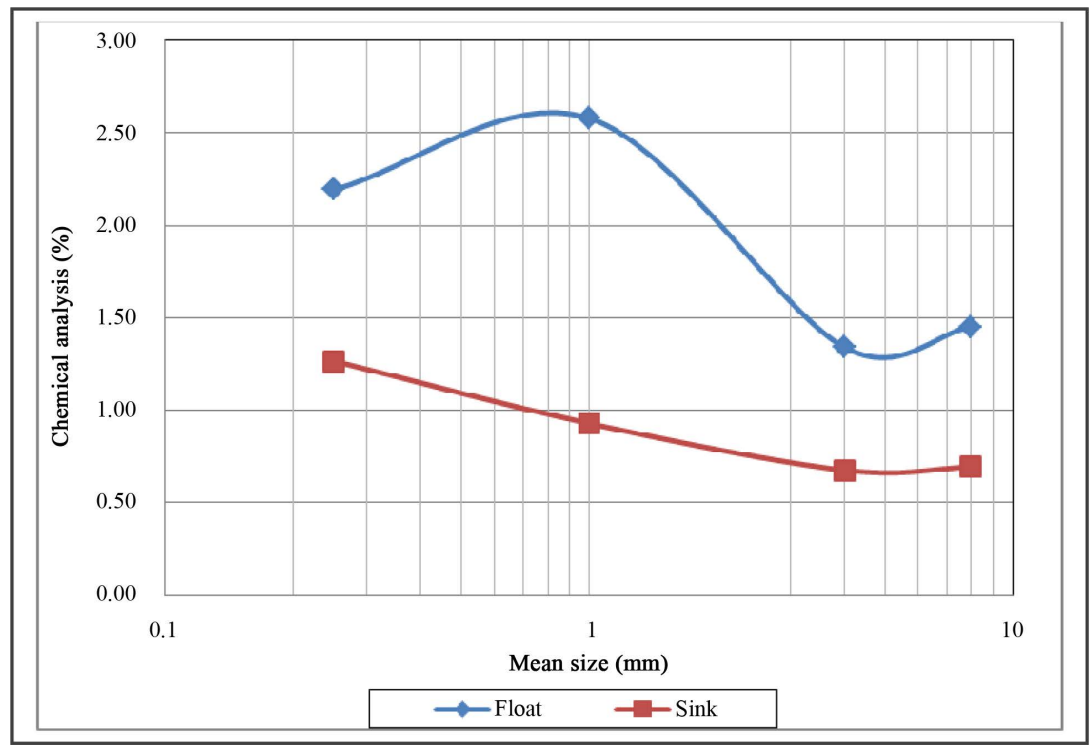

Figure 7. Chemical analysis of $\mathrm{NiO}$ according to the mean size of the products, which are obtained from the gravimetric separation.

passes with decreasing rotation frequency, starting with a rotation frequency of $180 \mathrm{rpm}$. For the size fraction $-8+$ $4 \mathrm{~mm}$, the non-magnetics products were passed at $140 \mathrm{rpm}$ and finally at $100 \mathrm{rpm}$, while the second fraction $-4+1$ $\mathrm{mm}$ was separated in two passes, due to its insufficient quantity (180 and $140 \mathrm{rpm})$. In each pass the magnetics are collected, weighted and assayed and the non-magnetics products are used to feed the next pass. For the fractions $-1+0.250 \mathrm{~mm}$ and $-0.250+0.063 \mathrm{~mm}$ the Induced Roll magnetic separator was used. The fraction $-1+$ $0.250 \mathrm{~mm}$ was separated in three passes with decreasing rotation frequency starting with $140 \mathrm{rpm}$ and electric current $\mathrm{I}=2.83$ Amps, while the fraction $-0.250+0.063 \mathrm{~mm}$ was separated also in two passes. Table 4 presents the results obtained from the magnetic separation of all the size fractions (except for the fraction $-0.063 \mathrm{~mm}$, which was not used). The chemical analysis of $\mathrm{NiO}$ in the fraction $-8+4 \mathrm{~mm}$ are $0.96 \%, 1.17 \%, 1.52 \%$ in the magnetic products $1,2,3$ respectively and $2.34 \%$ in the non-magnetic. It is seen that the non-magnetic product has the highest quality of $\mathrm{NiO}$. The weight distribution is $37.49 \%$ in the magnetic product $1,14.25 \%$ in the magnetic product $2,22.27 \%$ in the magnetic product 3 and $25.98 \%$ in the non-magnetic product. At the size fraction $-4+1 \mathrm{~mm}$, the quality of $\mathrm{NiO}$ in the non-magnetic product is similar to the one in the coarser size fraction 
Table 4. Results of magnetic separation.

\begin{tabular}{|c|c|c|c|c|c|c|c|c|c|}
\hline \multirow{2}{*}{$\begin{array}{l}\text { Size fraction } \\
\quad(\mathrm{mm})\end{array}$} & \multirow{2}{*}{ Products } & \multicolumn{2}{|c|}{ Weight (\%) } & \multicolumn{3}{|c|}{ Chemical analysis (\%) } & \multicolumn{3}{|c|}{ Distribution (\%) } \\
\hline & & of the fraction & of the initial & $\mathrm{Fe}_{2} \mathrm{O}_{3}$ & $\mathrm{SiO}_{2}$ & $\mathrm{NiO}$ & $\mathrm{Fe}_{2} \mathrm{O}_{3}$ & $\mathrm{SiO}_{2}$ & $\mathrm{NiO}$ \\
\hline \multirow{6}{*}{$-8+4$} & Magnetic 1 & 50.6 & 23.9 & 31.70 & 42.77 & 0.96 & 68.97 & 41.69 & 37.49 \\
\hline & Magnetic 2 & 15.9 & 7.5 & 24.24 & 49.70 & 1.17 & 16.57 & 15.22 & 14.25 \\
\hline & Magnetic 3 & 19.1 & 9.0 & 16.04 & 60.74 & 1.52 & 13.14 & 22.30 & 22.27 \\
\hline & Non-magnetic & 14.4 & 6.8 & 2.12 & 74.97 & 2.34 & 1.31 & 20.80 & 25.98 \\
\hline & Total & 100.0 & 47.3 & 23.26 & 51.94 & 1.30 & 100 & 100 & 100 \\
\hline & Magnetic 1 & 74.3 & 21.3 & 32.91 & 31.89 & 1.38 & 91.51 & 60.74 & 61.67 \\
\hline \multirow{3}{*}{$-4+1$} & Magnetic 2 & 13.5 & 3.9 & 14.54 & 47.38 & 2.76 & 7.37 & 16.44 & 22.52 \\
\hline & Non-magnetic & 12.1 & 3.5 & 2.48 & 73.58 & 2.17 & 1.12 & 22.82 & 15.81 \\
\hline & Total & 100.0 & 28.7 & 26.74 & 39.03 & 1.66 & 100 & 100 & 100 \\
\hline \multirow{5}{*}{$-1+0.250$} & Magnetic 1 & 59.0 & 6.0 & 28.34 & 34.84 & 2.27 & 78.83 & 48.38 & 48.03 \\
\hline & Magnetic 2 & 14.0 & 1.4 & 17.67 & 42.44 & 3.84 & 11.67 & 13.99 & 19.30 \\
\hline & Magnetic 3 & 7.0 & 0.7 & 14.63 & 45.36 & 4.32 & 4.83 & 7.48 & 10.87 \\
\hline & Non-magnetic & 20.0 & 2.0 & 4.96 & 64.09 & 3.04 & 4.67 & 30.15 & 21.81 \\
\hline & Total & 100.0 & 10.2 & 21.21 & 42.49 & 2.79 & 100 & 100 & 100 \\
\hline \multirow{4}{*}{$-0.250+0.063$} & Magnetic 1 & 86.4 & 4.5 & 22.77 & 38.17 & 2.61 & 96.73 & 80.02 & 87.87 \\
\hline & Magnetic 2 & 5.4 & 0.3 & 8.60 & 50.35 & 4.21 & 2.29 & 6.61 & 8.85 \\
\hline & Non-magnetic & 8.2 & 0.4 & 2.44 & 67.19 & 1.03 & 0.98 & 13.37 & 3.27 \\
\hline & Total & 100.0 & 5.2 & 20.34 & 41.21 & 2.57 & 100 & 100 & 100 \\
\hline-0.063 & Total & 100.0 & 8.7 & 19.21 & 44.13 & 1.87 & 100 & 100 & 100 \\
\hline Grand Total & & 100 & & & & & & & \\
\hline
\end{tabular}

(2.17\%). On the other hand, the weight distribution is much lower (15.81\%). It is noted that the $\mathrm{NiO}$ content in the magnetic 1 product is $1.38 \%$ with a high weight distribution $(61.67 \%)$ which means that a great quantity of $\mathrm{NiO}$ goes to the magnetic 1 product.

The results of the magnetic separation of size fractions $-1+0.250 \mathrm{~mm}$ and $-0.250+0.063 \mathrm{~mm}$ are quite satisfactory. At the size fraction $-1+0.250 \mathrm{~mm}$ the $\mathrm{NiO}$ content is $2.27 \%$ with $48.03 \%$ weight distribution in the magnetic product 1 . It is pointed out that the $\mathrm{NiO}$ content in the magnetic 3 product is $4.32 \%$, which is the highest quality of $\mathrm{NiO}$ of the whole process. However, the weight distribution of this product is low $(10.87 \%)$. This fact is justified by its microscopic investigation, where a large proportion of binder material grains have been found. Concerning the size fraction $-0.250+0.063 \mathrm{~mm}$, the $\mathrm{NiO}$ content in the magnetic product 1 is $2.61 \%$ with a very high weight distribution (87.87\%) (Figure 8(a) and Figure 8(b)). The latter results combined with the high quality of $\mathrm{NiO}$ in the magnetic 2 product $(4.21 \%)$ leads to the fact that this size fraction is better separated with the specified method (Figure 9).

\section{Discussion and Conclusions}

The nickel iron ore of Agios Athanasios in Kastoria area develops in the form of layers over ophiolites. Above the ophiolites, there are successive layers of silicate ore, saprolite ore, clay ore and iron ore zone. The nickeliferous ore zone is covered by the molassic conglomerates on the top. The main minerals of the nickel iron ore are hematite, goethite, quartz and lizardite, while in less extend are garnierite, saponite, willemzeite and sepiolite, and scarcers are chromite, calcite and nepouite. Hematite and goethite are mainly observed in the form of veins, as well as isolated crystals within the binder material, which were mainly constituted of compact masses of quartz, as well as garnierite, lizardite, saponite, willemzeite, sepiolite and nepouite. Furthermore, isolated 




(a)

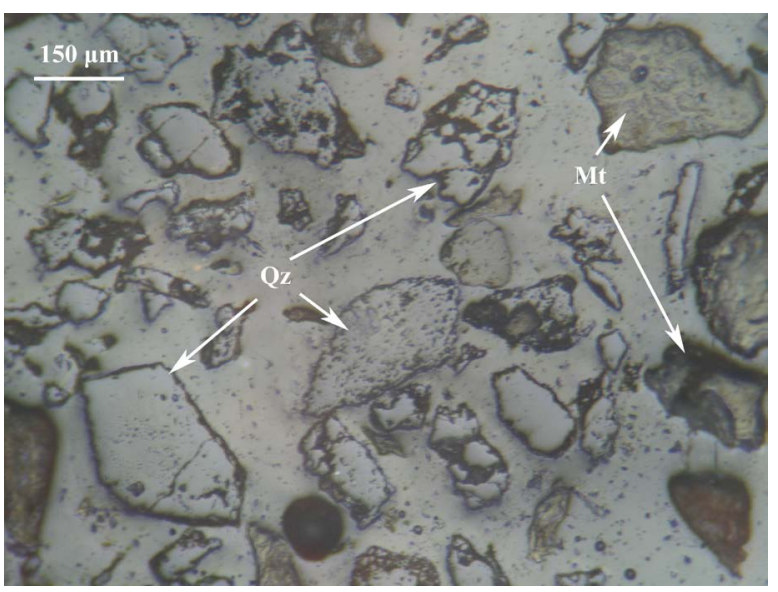

(b)

Figure 8. (a) Individual grains of binder material (Mt) and quartz (Qz), as well as non-liberated hematite (He) grains from binder material (Magnetic product 1, size fraction $-0.250+0.063 \mathrm{~mm}$ ); (b) Multiple quartz (Qz) grains and individual grains of binder material (Mt) (Non-magnetic product, size fraction $-0.250+0.063 \mathrm{~mm}$ ). Reflected light, / $/ \mathrm{Nicols}$.



Figure 9. Chemical analysis of $\mathrm{NiO}$ according to the mean size of the products, which are obtained from the magnetic separation.

clastic granules of chromite and veins of calcite of secondary origin were observed. A progressive transition of the goethite into hematite is occurred, due to dehydration. Nickel is mainly found in garnierite, willemzeite and nepouite, which are along with quartz the main components of the binder material.

The results of the gravimetric separation lead to the conclusion that in all size fractions nickel is enriched in the light size fraction and distributed mainly in the floating products. The best nickel enrichment was achieved in the $-1+0.250 \mathrm{~mm}$ fraction with a $\mathrm{NiO}$ content of $2.58 \%$ and a distribution $94.49 \%$. There also occurs high percentage of $\mathrm{NiO}$ in the floating product of the size fraction $-0.250+0.063 \mathrm{~mm}$ fraction $(2.19 \%)$.

The results of magnetic separation lead to the conclusion that nickel is enriched mainly in magnetic products, while small concentrations were observed in the non-magnetic products. Exception was the coarser size fraction $-8+4 \mathrm{~mm}$, where there was the highest concentration of $\mathrm{NiO}$ in the non-magnetic product $(2.34 \%)$. This is due to the insufficient liberation of the binder material. The best nickel enrichments were performed in size fractions $-1+0.250 \mathrm{~mm}$ and $-0.250+0.063 \mathrm{~mm}$. The $\mathrm{NiO}$ content in magnetic product 3 of the size fraction $-1+$ $0.250 \mathrm{~mm}$ was $4.32 \%$, while in the magnetic product 2 of size fraction $-0.250+0.063 \mathrm{~mm}$ was $4.21 \%$. 
The relatively high nickel concentration $(1.87 \%)$ in the fine size fraction $-0.063 \mathrm{~mm}$ is worth noticing. This can be explained by the factor that $\mathrm{Ni}$ is found in binder material; as a result, through breaking and sieving, the binder material's granules are led to this finer size fraction. The microscopic investigation of this size fraction confirms the presence of a significant percentage of binder material granules, which are enriched in quartz, garnierite, willemzeite and nepouite.

The comparison between the two washability treatment methods leads to the observation that the gravimetric separation provides a better nickel distribution in all size fractions, while the magnetic separation provides higher nickel analysis. In conclusion, satisfactory nickel content in combination with the better distribution in $\mathrm{NiO}$ in the gravimetric separation makes it the appropriate enrichment method for this specific deposit in regard to the magnetic separation method.

\section{References}

[1] Apostolikas, A. (2009) Nickel Deposits. Efyra Publications, Ioannina. (In Greek)

[2] Katzagiannakis, N., Alevizos, G., Stamboliadis, E., Stratakis, A. and Petrakis, E. (2014) Mineralogical Investigation and Washability Treatment of the Nickeliferous Lateritic Deposit of Nome (Albania). Geomaterials, 4, 105-115. http://dx.doi.org/10.4236/gm.2014.43011

[3] Alevizos, G. and Repouskou, E. (2011) Ore Microscopy and Microanalysis of the Nickeliferous Iron Ores from KomninaVermion Area (N.W. Greece). Geomaterials, 1, 46-50. http://dx.doi.org/10.4236/gm.2011.12008

[4] Bourman, R. and Clifford, O. (2002) A Critique of the Schellmann Definition and Classification of "Laterite". Catena, 47, 117-131. http://dx.doi.org/10.1016/S0341-8162(01)00178-3

[5] Skarpelis, N. (2006) Lateritization Processes of Ultramafic Rocks in Cretaceous Times: The Fossil Weathering Crusts of Mainland Greece. Journal of Geochemical Exploration, 88, 325-328. http://dx.doi.org/10.1016/j.gexplo.2005.08.066

[6] Eliopoulos, D.G., Economou-Eliopoulos, M., Apostolikas, A. and Golightly, J.P. (2012) Geochemical Features of Nickel-Laterite Deposits from the Balkan Peninsula and Gordes, Turkey: The Genetic and Environmental Significance of Arsenic. Ore Geology Reviews, 48, 413-427. http://dx.doi.org/10.1016/j.oregeorev.2012.05.008

[7] Tsirambides, A. and Filippidis, A. (2012) Metallic Mineral Resources of Greece. Central European Journal of Geosciences, 4, 641-650. http://dx.doi.org/10.2478/s13533-012-0110-2

[8] Eliopoulos, D.G. and Economou-Eliopoulos, M. (2000) Geochemical and Mineralogical Characteristics of Fe-Ni and Bauxitic-Laterite Deposits of Greece. Ore Geology Reviews, 16, 41-58. http://dx.doi.org/10.1016/S0169-1368(00)00003-2

[9] Anders, B., Reischmann, T. and Kostopoulos, D. (2006) Zircon Geochronology of Basement Rocks from the Pelagonian Zone, Greece: Constraints on the Pre-Alpine Evolution of the Westernmost Internal Hellenides. International Journal of Earth Sciences, 96, 639-661. http://dx.doi.org/10.1007/s00531-006-0121-7

[10] Papanikolaou, D. (2013) Tectonostratigraphic Models of the Alpine Terranes and Subduction History of the Hellenides. Tectonophysics, 595-596, 1-24. http://dx.doi.org/10.1016/j.tecto.2012.08.008

[11] Skarpelis, N., Laskou, M. and Alevizos, G. (1993) Mineralogy and Geochemistry of the Nickeliferous Lateritic Iron-Ores of Kastoria, N.W. Greece. Chemical Erde, 53, 331-339.

[12] Mountrakis, D. (1982) Emplacement of the Kastoriaophiolite on the Western Edge of the Internal Hellenides (Greece). Ofioliti, 7, 397-405. 